\title{
ADMINISTRATIVE PROCEDURE REFORM IN PENNSYLVANIA
}

\section{By Clark Byse $\dagger$}

Three years ago the Commonwealth of Pennsylvania enacted the "Administrative Agency Law" and the "Pennsylvania Register Act" to regulate certain aspects of administrative procedure, judicial review of administrative adjudications, and publication of administrative regulations. ${ }^{1}$ Two years later the Pennsylvania Register Act was repealed; ${ }^{2}$ the Administrative Agency $L$ aw was amended; ${ }^{3}$ and the Joint State Government Commission was instructed to study and report to the next session of the General Assembly concerning "the problems of making uniform the practice and procedure before administrative agencies of the State Government and of appeals therefrom, as well as the review of regulations promulgated by such agencies; and . . . the problem of publishing all regulations of State agencies in one register, and making their validity contingent on such publication . . "4 The purpose of this paper is to consider some of the more significant reform proposals which have been or will be urged upon the Joint State Government Commission in its administrative law study. Because proposals for reform are intelligible only in light of that which has gone before, discussion of the specific proposals is preceded by a brief survey of the background and provisions of the Agency Law and the Register Act.

\section{The Administrative Agency Law and Pennsylvania Register ACT of 1945}

The origins of Pennsylvania administrative procedure legislation, like those of its federal counterpart, ${ }^{5}$ are to be found in the activities of the organized bar. In 1938 the Pennsylvania Bar Associa:

$\dagger$ B.E., 1935, State Teachers College, Oshkosh, Wisconsin; LL.B., 1938, University of Wisconsin; LL.M., 1939, Columbia University; Professor of Law, University of Pennsylvania.

I wish at the outset to express my indebtedness to the authors of the articles appearing in the Symposium on State Administrative Procedure, 33 IowA L. REv. 193375 (1948). The reader desiring additional information and views concerning many of the topics discussed in this paper will find the symposium a valuable reference.

1. Pa. Laws 1945 , Nos. 442 and 443.

2. Pa. Laws 1947 , No. 509.

3. Pa. Laws 1947, No. 541 .

4. Pa. House Res. No. 40 (1947). The Resolution specifically requested the Joint State Government Commission to present "recommendations" and "drafts of proposed legislation."

5. Federal Administrative Procedure Act, 60 Stat. 237, 5 U. S. C. A. $\$ 1001-$ 1011 (Supp. 1946). 
tion created a Special Committee on Administrative Law to "analyze the present practices and procedures before the various State administrative agencies . . ." 8 The Committee energetically began its task of assembling the necessary data, and at the next meeting of the Bar Association submitted a lengthy report describing the work it had completed and outlining its future action. ${ }^{7}$ The report listed the administrative orders for which there were no statutory provisions for direct judicial review, discussed the methods of securing review of such orders, and tabulated the various statutory provisions governing judicial review of orders expressly made reviewable by statute. ${ }^{8}$ The report also stated that subcommittees were at work gathering information concerning the organization, functions, duties and procedures of Pennsylvania administrative tribunals and that the Committee intended to submit a "detailed report" concerning these matters at the next meeting of the Association. ${ }^{9}$ But the detailed report was not forthcoming at the next Association meeting. Possibly the Committee found that laying bare the actual workings of the administrative process is considerably more difficult than compiling data concerning judicial review. ${ }^{10}$ Also, by this time the Committee had decided that its research should be coordinated with that of the Joint State Government Commission which had recently instituted a study of Pennsylvania administrative procedure. ${ }^{11}$

After conducting a series of hearings, the Joint State Government Commission submitted a brief report to the General Assembly recommending enactment of two proposed bills dealing with adminis-

6. 44 PA. B. A. REP. 134 (1938). At the next meeting of the Association the Committee was instructed to consider the preparation of remedial legislation. $45 \mathrm{PA}$. B. A. REP. 112 (1939). In 1941 the Association created a permanent Section on Administrative Law and therefore discharged the Committee. 47 PA. B. A. REP. 27, 37 (1941).

7. 45 PA. B. A. ReP. 344-419 (1939).

8. In this, its first report, the Committee observed ". . . existing law is in a condition of chaos and confusion which merits the early sponsoring of remedial measures." 45 PA. B. A. REP. 344, 350 (1939). See also the article by Mr. Gilbert Nurick, Secretary of the Committee, Much Ado About Something-The Story of Administrative Chaos in Pennsylvania, 45 DICK. L. Rev. 85 (1941).

9. 45 PA. B. A. Rep. 344, 418 (1939).

10. See the statement of Mr. Gilbert Nurick, Secretary of the Committee, 45 PA. B. A. REP. 112 (1939) : “. . we have started a questionnaire circulating among the various tribunals, to ascertain their procedure . . . but the response has been practically negative." The 1940 report of the Committee, however, states: "A subcommittee prepared a questionnaire which was circulated among the agencies. Practically all of these have been returned." 46 PA. B. A. REP. 248 (1940).

11. Report of Committee on Administrative Law, 46 PA. B. A. REP. 248 (1940). The Joint State Government Commission is a joint legislative commission of the General Assembly. It is composed of senators and representatives, and it was established to serve the General Assembly as "a fact-finding body and as an authoritative source of information." See Jornt STATE GoverNMENT Commission, A Statement of the History, Purposes, and Activities of the Joint State Governament Commission of the General Assembly of Pennsylvania (1940); see also PA. Stat. ANN., tit. 46, §§ 65-68 (Purdon, 1941). 
trative procedure, judicial review, and publication of administrative regulations. ${ }^{12}$ In the meantime, the Section on Administrative Law of the Pennsylvania Bar Association had also prepared drafts of very similar bills. ${ }^{13}$ At the 1943 session of the General Assembly, bills drafted by the Section on Administrative Law and approved by the Pennsylvania Bar Association were introduced in the Senate. ${ }^{14}$ The bills were passed by the Senate in amended form, but were not approved by the House of Representatives. At the 1945 session of the General Assembly, however, the efforts of the Bar Association were finally rewarded by enactment of the Administrative Agency Law ${ }^{15}$ and the Pennsylvania Register Act. ${ }^{16}$

The Administrative Agency Law provides for publication of administrative regulations, ${ }^{17}$ procedure for administrative adjudications, ${ }^{18}$ and judicial review of adjudications. ${ }^{19}$ The coverage of the Law is stated in broad terms to include administrative agencies "having Statewide jurisdiction, empowered to determine or affect rights, privileges, immunities or obligations . . ." 20 But Section 51 drastically limits this coverage by declaring that the sections of the Law governing procedure for adjudications and judicial review of adjudications shall not apply to an adjudication from which an appeal to a court is

12. Joint State Government Commission, Report to the General Assembly of the Commonwealta of Pennsylvania on Uniform Practice and Procedure Before Departments, Boards and Commissions of the Commonwealth (1943).

13. 48 PA. B. A. REP. 239 (1942). Note that the Special Committee on Administrative Law of the Bar Association had been discharged in 1941 upon creation of the Section on Administrative Law. See note 6 supra.

14. Sen. Bills Nos. 53 and 54, Pa. Gen. Ass., 1947 Sess. See Report of Section on Administrative Law, 49 PA. B. A. REP. 170 (1943).

15. Pa. Laws 1945, No. 442. The present version of the Agency Law appears in PA. Stat. ANN., tit. 71, $\S 1710.1-1710.51$ (Purdon, Supp. 1947).

16. Pa. Laws 1945, No. 443, repealed by Pa. Laws 1947, No. 509.

17. \$21. "Regulation" is defined as "any rule, regulation or order in the nature of a rule or regulation, generally applicable to the public, promulgated by an agency authorized by statute so to do, but shall not be construed to include the name or facts of any adjudication giving rise to such regulation." $\$ 2(\mathrm{e})$.

18. $\$ 31-35$. "Adjudication" is defined as "any final order, decree, decision, determination or ruling by an agency affecting personal or property rights, privileges, immunities or obligations of any or all of the parties to the proceeding in which the adjudication is made, but shall not mean any final order, decree, decision, determination or ruling based upon a proceeding before a court, or which involves the seizure or forfeiture of property, or which involves paroles or pardons." $\$ 2(a)$.

19. $\S 41-45$. The Agency Law also contains two sections (11 and 12) providing for representation of parties before agencies and for the discipline of attorneys practicing before agencies.

20. "Agency" is defined as "any department, departmental administrative board or commission, independent administrative board or commission, officer or other agency of this Commonwealth, now in existence or hereafter created, having Statewide jurisdiction, empowered to determine or affect private rights, privileges, immunities or obligations by regulation or adjudication, but shall not inciude a court of record nor a magistrate, alderman or justice of the peace." $\$ 2(\mathrm{~b})$. 
provided by another statute or which is made final by another statute. ${ }^{21}$ This point deserves to be underscored: the adjudication and judicial review provisions of the Administrative Agency Law apply only to adjudications of agencies operating under statutes which neither expressly permit nor preclude an appeal from the adjudication. The coverage of the Law, therefore, is much less extensive than a hasty reading would indicate, for most of the statutes administered by the major state agencies, as well as those executed by many of the less important tribunals, expressly provide for a direct appeal. ${ }^{22}$

As originally enacted, the Administrative Agency Law provided for publication of regulations pursuant to the terms of the Pennsylvania Register Act. Briefly stated, the Register Act required publication of regulations in the "Pennsylvania Register" within forty-five days after their adoption. ${ }^{23}$ With the repeal of the Register Act in 1947, the Agency Law was amended to provide simply that regulations then in effect or thereafter adopted "shall have no effect, unless they are printed and made available, upon written request, within thirty days after the date of adoption." 24

The procedure prescribed for adjudications subject to the Administrative Agency Law requires: reasonable notice and opportunity for hearing in a proceeding in which the technical rules of evidence need not be applied and at which all relevant evidence of reasonable probative value may be received; an opportunity to submit briefs; oral argument upon substantial issues at the discretion of the agency;

21. This broad exemption was included in the Law only because "it was certain that the bill would not pass unless this exemption were incorporated." Report of Section on Administrative Law, 52 PA. B. A. Rep. 179, 181 (1946).

Section 51 provides for other exemptions from some or all of the provisions of the Law. These relate primarily to proceedings involving taxes, bonuses, and the seizure and liquidation of banks, building and loan associations, and insurance companies.

22. See parts II and III of the Report of the Committee on Administrative Law, 45 PA. B. A. REP. 344, 348-374 (1939). See also Faught, The Multiplication of Administrative Agencies and Problems of Judicial Rerieze in Pennsylvania, 13 Texp. L. Q. 30, 32-33 (1938) ; Schulman, Administrative Procedure-A Survey of Suggested Reforms, 15 TEMP. L. Q. 1, 19-26 (1940).

23. The Register Act provided for the creation of a new publication to be known as the "Pennsylvania Register" to be published under the supervision of the "Pennsylvania Register Board" consisting of the Secretary of Property and Supplies, the Secretary of the Commonwealth, the Attorney General (or their representatives) and the Director of the Legislative Reference Bureau as chairman. Regulations in effect at the effective date of the Act were to be codified and filed with the Director of the Legislative Reference Bureau within 100 days; future regulations were to be published in the Register within 45 days after adoption; regulations not filed or published within the specified periods would expire. However, a regulation could become effective without prior publication upon certification by the Department of Justice that because of an emergency or other compelling extraordinary circumstance the public interest so required. The first issue of the Register was to be published within 150 days after the effective date of the Register Act and at least monthly thereafter. Once a year a cumulative index was to be published, bringing all agency regulations which remained in effect down to date. The effective date of the Act was Jan. 1, 1946. The first volume of 1100 odd Dages of regulations is dated June 1,1946 .

24. PA. Stat. Ann., tit. 71, § 1710.21 (Purdon, Supp. 1947). 
findings and reasons for the administrative determination; and service of the findings, reasons, and final order upon the parties or their counsel. The Law also authorizes agencies to adopt rules of practice for adjudication proceedings.

The judicial review sections of the Law enable aggrieved persons to secure judicial review of the administrative adjudications by taking an appeal therefrom to the Court of Common Pleas of Dauphin County within thirty days after service of the final order. The procedure for the appeal is governed by rules adopted by the Supreme Court pursuant to Section 42 of the Agency Law. ${ }^{25}$ The appellant is not precluded from questioning the validity of the substantive statute involved, but he may not raise questions not presented to the agency unless allowed by the court for good cause. Existing equitable remedies are specifically preserved. The court may grant a supersedeas upon such conditions as it shall prescribe. The appeal is to be heard on the administrative record. The administrative order is to be affirmed unless the court shall find that it violates constitutional rights of the appellant, or is not in accordance with law, or that a necessary finding of fact is not supported by substantial evidence, or that the adjudication provisions of the Law have been violated. If the administrative order is not affirmed, the court may set it aside, modify it in whole or in part, or remand the proceeding to the agency for further disposition in accordance with the order of the court.

The foregoing resume demonstrates the rudimentary character of the Administrative Agency Law. First, the Section 51 exemption of adjudications for which an appeal to a court is provided by another statute renders the Law inapplicable to the adjudicative activities of most of the more important state agencies. Second, the Law is almost exclusively concerned with the procedure for, and court review of, formal administrative adjudications. Topics such as the following, which have been the subject of legislation in other jurisdictions, ${ }^{26}$ are not covered by the Law: procedure to be followed in enacting regulations or making investigations; judicial review, by declaratory

25. Rules of Civil Procedure Governing Appeals from Certain Administrative Agencies, effective Feb. 4, 1946. Goodrich-Amram, Pennsylvania Procedural Rules Service with ForMs, Issue '46 (1940).

26. For a discussion of recent legislative developments in the field of state administrative law which I have found particularly helpful, see Nathanson, Recent Statutory Developments in State Administrative Law, 33 IowA L. REv. 252 (1948). See also Hoyt, The Wisconsin Administrative Procedure Act [1944] WIS. L. REv. 214; Kleps, The California Administrative Procedure Act (1947), 22 J. STATE B. of CAIIF. 391 (1947) ; Stason, The Model State Administrative Procedure Act, 33 Iowa L. Rev. 196 (1948) ; Tunks, The Model Act Route to Improvement of Iove Administrative Procedure, 33 IowA I. REv. 356 (1948) ; Federal Administrative Procedure Act, 60 Stat. 237, 5 U. S. C. A. $\$ \$ 1001-1011$ (1946). The provisions of the Model Act and of the Federal Act are compared in Abel, The Double Standard in Administrative Procedure: Model Act and Federal Act, 33 IowA L. REv. 228 (1948). 
judgment or otherwise, of administrative regulations; authorization of declaratory rulings by administrative agencies; opportunity for informal settlements; and establishment of an office or division of administrative procedure to exercise a continuous responsibility of examination and supervision of administrative procedure in the state. Third, even those procedures that are governed by the Law are not regulated in a comprehensive or detailed manner: the provision for publication of regulations is stated in terms of a rough requirement of availability upon written request within thirty days after adoption; some of the adjudication requirements are but general provisions declaratory of basic constitutional safeguards; and the adjudication sections contain no explicit provisions for official notice, utilization of official records, introduction of written evidence, an intermediate report or proposed decision, or for separation of the functions of investigating and prosecuting from the function of deciding.

It should be emphasized that to enumerate items which either are not presently covered by the Agency Law or are regulated in general terms is not to suggest that those matters should be controlled by statute. On the contrary, the only purpose of the enumeration is to put the Agency Law in proper perspective before proceeding to a discussion of the proposals to reform the law.

\section{ReForm Proposals}

Suggestions for administrative procedure reform in Pennsylvania range from outright repeal of the Administrative Agency Law to replacing it with a statute copied almost verbatim from the Federal Administrative Procedure Act. Intermediate proposals recommend retention and amendment of the Law.

\section{A. Proposal to Repeal the Administrative Agency Law}

House Bill No. 1210 of the 1947 session of the General Assembly provided for the outright repeal of the Administrative Agency Law. ${ }^{27}$ I do not know what motivated the sponsor of the bill. But it is interesting to note how plausible an argument can be made in support of the position that general administrative procedure legislation is necessarily undesirable, and, presumably therefore, if already enacted, should

27. This bill was passed by the House of Representatives by a vote of 189 to 0 . 30 PA. LEgrs. J. 1905 (April 24, 1947). It was amended in the Senate to provide for (1) repeal of the sections of the Agency Law requiring publication of regulations pursuant to the Pennsylvania Register Act and (2) making regulations available upon written request within thirty days after the date of adoption. The House concurred in the Senate amendments, and in this form it became law. Pa. Stat. And., tit. 71, $\$ 1710.21$ (Purdon, Supp. 1947). 
be repealed. The proponent of this view could urge that administrative agencies exercise extremely diverse functions, ranging from the issuance of a driver's license to the fixing of prices; that these diverse functions are exercised by administrators of widely varying capacities and backgrounds, ranging from the part-time lay official to the full time professional expert; that, in short, the differences are more pronounced than the likenesses; and that therefore legislation prescribing uniform administrative procedure will either be couched in such general terms as to be virtually meaningless as a legislative prescription or be so concrete as to work hardship in specific cases. ${ }^{28}$ The argument finds support in the Report of the director of the most notable study of state administrative procedure undertaken in this country. ${ }^{29}$ On this point, Mr. Benjamin concluded:

"My description of diversity in existing procedure has . . . shown that much of the existing diversity exists for reasons that are not merely valid but inescapable. Thus a uniform procedure would be impossible, if it were thought desirable. And this would be so even if a code were confined to an attempt to provide the fundamentals of fair procedure, such as adequate specification of the issues, on which all would agree. A provision that would be appropriate to secure adequate specification of the issues in an unfair labor practice case in the State Labor Relations Board, or in a proceeding for the revocation of a doctor's license, would be inapplicable to a representation case in the State Labor Relations Board, or to a driver's license case in the Bureau of Motor Vehicles, or to a benefit claim case in unemployment insurance, or to a rate case in the Public Service Commission." 30

There is much to be said for this point of view, particularly when the question is whether a detailed code of administrative procedure should or should not be enacted. If the present issue were one of adoption or non-adoption of a statute containing the provisions of the Agency Law, my vote would be cast against adoption, primarily because the Section 51 exemption and the broad definitions of "agency" and "adjudication" do not provide for a careful selection of the agencies and agency activities to which the Law should apply. ${ }^{31}$ But it does not follow, that the Law should be repealed at this time. It has been in effect for three years, and there is little or no indication that it has operated harshly or created undue difficulties. Also, once there has

28. See Cohen, Legislative Injustice and the Supremacy of "Law," 26 NEB. L. REv. 323 (1947).

29. By Robert M. Benjamin of the New York bar. Benjamin, Administrative Adjudicatron IN THE STATE of NEW YoRK (1942), hereinafter reeferred to as "BeNJAMIN REPORT."

30. Id. at 35 .

31. This point is more fully developed in part II D 5 of this paper, infra pp. 44-45. 
been an intelligent selection of the particular agencies and agency activities to which the Law should apply, agency compliance with its requirements-most of which are stated in broad and general termsshould in some measure assist private interests while not hindering effective administration. Such defects as exist should be corrected after careful study. They do not, however, appear sufficiently grave to warrant repeal of the entire statute.

\section{B. Proposal to Adopt Provisions of Federal Administrative Procedure Act}

Senate Bill No. 261 of the 1947 session of the General Assembly would have replaced the Administrative Agency Law with a statute copied almost verbatim from the Federal Administrative Procedure Act. The Bill was referred to the Committee on State Government, which did not report it to the Senate. In this, the Committee acted wisely, for at least two attributes of the Federal Act make it particularly inapposite as a charter for state administrative procedure legislation.

Adoption of the Federal Administrative Procedure Act in 1946 was preceded by careful investigation of the actual functioning of the more important federal agencies, extensive hearings before Congressional committees, and significant compromises between the proponents of diversity and flexibility and those who wished to achieve greater uniformity. ${ }^{32}$ In the process of compromise the two opposing groups frequently reached formal agreement on particular wording, but each read the words to mean different things. ${ }^{33}$ This means that to a considerably greater extent than generally is true of legislative compromises, the significance of this legislation must await definitive interpretation by the Supreme Court. Surely, a state desiring to improve its administrative procedure should not slavishly copy a statute containing the ambiguities and compromises of the Administrative Procedure Act.

A second and more basic objection to adopting the federal provisions is that the Administrative Procedure Act was tailored for the federal administrative establishment. The studies which preceded its enactment, the testimony submitted to the Congressional committees, and the compromise proposals embodied in the Act were all

32. See generally Nathanson, Some Comments on the Administrative Procedure Act, 41 ILL. L. REv. 368 (1946).

33. See Conard, New Ways to Write Laws, 56 Y AlE L. J. 458, 461, n. 13. See also Dickinson, Administrative Procedure Act: Scope and Grounds of Broadened Judicial Review, 33 A. B. A. J. 434, 516: ". . the new statute . . . broadens ... the scope and measure of the review which the Federal Courts are henceforth required to make of administrative action ..."; with which compare statement of Attorney General Clark: "This [section] declares the existing law concerning the scope of julicial review." Sen. Doc. 248, 79th Cong., 2d Sess. 230 (1946), 
designed to secure workable procedures for the various federal agencies, rather than to fashion a model procedure code. If, as Mr. Benjamin has so convincingly shown, there are basic diversities in the procedures of a single state, ${ }^{34}$ it is hardly likely that a statute constructed expressly for the federal establishment will provide a satisfactory or workable pattern for the states. Even the National Conference of Commissioners on Uniform State Laws which began in 1939 to draft a Uniform Administrative Procedure Act for recommendation to the various states abandoned that endeavor in 1943, because in the field of administrative procedure uniformity among the states is neither desirable nor feasible. ${ }^{35}$

There may be specific provisions of the Federal Administrative Procedure Act which Pennsylvania would do well to enact. Whether there are, and if so, which provisions should be adopted, can only be determined after a critical investigation of existing administrative practices and procedures in Pennsylvania. I am reasonably certain, however, that no amount of study would indicate the desirability of enacting the almost verbatim copy of the Federal Act embodied in Senate Bill No. 261. Here, as throughout the entire field, the emphasis should be upon selective remedial measures determined after careful study rather than upon reform proposals based upon general theories and applying in an overall, and perhaps indiscriminate, fashion to diverse administrative activities.

\section{Proposal to Adopt the Model State Administrative Procedure Act}

After abandonment of the project to write a Uniform Administrative Procedure Act in 1943, the National Conference of Commissioners on Uniform State Laws directed its energies to the production of a Model State Administrative Procedure Act. ${ }^{36}$ As approved by the 1946 meeting of the Conference, the Model Act consists of 16 sections. $^{37}$ The Chairman of the Special Committee which drafted the Act has stated that the Act is intended "to serve as a verbal embodiment of the basic principles of common sense, justice, and fairness that

34. See note 30 supra.

35. Handbook of National Conference of Commisstoners on Uniform State Laws ANd Proceedings of the Fifty-THIRd ANNUAI Conference 83-86 (1943).

36. Ibid. The distinction drawn by the National Conference between a "Uniform" and a "Model" Act is as follows: "Where there is a demand for an Act covering the subject matter in a substantial number of the States, but where in the judgment of the National Conference of Commissioners on Uniform State Laws it is not a subject upon which uniformity between the States is necessary or desirable, but where it would be helpful to have legislation which would tend toward uniformity where enacted, Acts on such subjects are promulgated as Model Acts." National Conference of Commisstoners on Uniforir State Laws, Model State Administrative Procedure Act WiTh PREFATORY Note 8 (1946).

37. See National Conference of Commissioners on Uniform State Laws, Model State Administrative Procedure Act with Prefatory Note (1946). 
should be deemed of universal applicability wherever the affairs of mankind are subjected to regulation by governmental administrative processes." 38 Despite this statement of objective, neither the Chairman of the Special Committee nor the Conference presents the Model Act for "immediate and verbatim adoption in each of the forty-eight states" but rather put it forward "as an aid to the development of administrative procedure bills in those states that may be considering the adoption of such legislation." 39

Certainly, if the sponsor and draftsmen of the Model Act do not urge its verbatim adoption, their counsel and the warnings of $\mathrm{Mr}$. Benjamin argue strongly against such action in Pennsylvania. So far as I know, no legislator or other individual or group proposes enactment of the Model Act by the Commonwealth. In fact, the only public expression on the question of which I am aware specifically rejects the solution of patterning legislation after the Model Act. ${ }^{40}$ In view of this action of the Section on Administrative Law of the Pennsylvania Bar Association and of the position of the sponsor and draftsmen of the Model Act, it is unlikely that adoption of that Act will be considered seriously by the Joint State Government Commission. Additional discussion of the Model Act at this time, therefore, hardly seems necessary. ${ }^{41}$

\section{Proposals to Amend the Administrative Agency Law}

The Section on Administrative Law of the Pennsylvania Bar Association has declared its opinion that future legislative reform of administrative procedure in the Commonwealth should be based upon retention of the Administrative Agency Law "and proceeding through amendments to improve that statute and to extend its coverage . . ."42 This position of the group which has been the driving force for administrative procedure reform, coupled with the action of the 1947 Session of the General Assembly in rejecting the extremes of outright

38. Stason, supra note 26 , at 200.

39. Stason, supra note 26, at 208; see also Fuchs, The Model Act's Division of Administrative Proceedings into Rule-Making and Contested Cases, 33 IowA L. Rev. 210, 213 (1948).

40. Report of Section on Administrative Laze, 19 PA. B. A. Q. 386 (1948).

41. Readers particularly interested in the Model Act should consult the Symposinum on State Administrative Procedure, 33 Iowa L. REv. 193-375 (1948); they ought also examine the experiences of Missouri and Wisconsin which have enacted administrative procedure statutes largely based upon the provisions of the Model Act. See Stason, supra note 26, at 209, n. 19; Hoyt, note 26 supra. Attention is also invited to the 1948 Report of the Committee on Administrative Laze of the Association of the Bar of the City of New York, concluding that "neither the Model State Administrative Procedure Act nor any similar general statute would be a desirable addition to New York State statutory law." 3 RECORD OF Ass'N. OF B. OF N. Y. 207 (1948).

42. In arriving at this conclusion, the Section considered and rejected suggestions that it recommend legislation patterned after either the Federal Administrative Procedure Act or the Model Act of the National Conference of Commissioners on Uniform State Laws. Report of Section on Administrative Law, 19 PA. B. A. Q. 386 (1948). 
repeal or replacement of the Agency Law with a Pennsylvania copy of the Federal Administrative Procedure Act, suggest that the Joint State Government Commission will give more serious consideration to recommendations to amend the Law than to any of the more drastic proposals discussed above.

\section{(1) Procedure in Adopting Regulations: ${ }^{43}$ Public Participation and Deferred Effectiveness}

The 1943 Report of the Joint State Government Commission concerning uniform practice and procedure before administrative agencies of the Commonwealth stated that in only a "few instances" did agencies give notice and public hearing before adopting administrative regulations. ${ }^{44}$ Believing this to be a defect, the Commission in its draft of a proposed Administrative Agency Law provided that an agency "having authority to promulgate, amend, or repeal regulations may do so only after public hearing following reasonable notice as the agency may deem appropriate" and that adoption, amendment, or repeal of a regulation would be ineffective "unless published in the Pennsylvania Register at least ten days before the date on which it is to become effective." 45 The Commission's draft also authorized adoption and immediate effectiveness of a regulation in cases where the Governor certified that because of an emergency or other compelling extraordinary circumstances, the public interest required that the regulation should become effective without delay. ${ }^{46}$ These recommendations of the Commission were not accepted by the General Assembly: the Administrative Agency Law as enacted contained no provision for notice and hearing in making regulations and only required publication within forty-five days after adoption of the regulation. ${ }^{47}$ In view of the Commission's stand in 1943 and of the fact that the Federal Administrative Procedure Act and the Model Act contain provisions concerning these topics, it may be anticipated that the Commission will give serious consideration to recommending

43. The definition of regulation contained in the Administrative Agency Law is set forth note 17 supra. The Section on Administrative Law of the Pennsylvania Bar Association would amend that definition to read as follows: "Regulation' means any rule, regulation or order of general application and future effect promulgated by an agency under statutory authority prescribing the practice or procedure before such agency or interpreting or implementing any statute enforced or administered by such agency." See Report of Section on Administrative Lav, 19 PA. B. A. Q. 386, 387; Sen. Bill No. 95, Pa. Gen. Ass. 1947 Sess. For an excellent analysis of the problem of defining regulation, see Davis, Administrative Rules-Interpretative, Legislative, and Retroactive, 57 Y ALE L. J. 919, 919-924 (1948).

44. Joint State Government Commission, op. cit. supra note 12, at 1.

45. $I d$. at $16,17$.

46. Id. at 17 .

47. The "regulation procedure" of the original Administrative Agency Law is set forth in $\$ \S 21-23$ of $\mathrm{Pa}$. Laws 1945, No. 442. 
legislative action in this field. Should it do so, it is my opinion that it should not adhere to its 1943 position.

The primary objective to be achieved by public participation in the process of making administrative regulations is to assure fair and informed administrative action by enabling the affected interests to present facts within their knowledge and their views concerning the merits and defects of the proposed action. ${ }^{48}$ A second objective of public participation is to give the regulated groups a feeling of sharing in the regulatory task, to satisfy them that their interests have been fairly and adequately considered, and thereby to secure their cooperation in administration of the regulations. ${ }^{49}$

A public hearing may be the most appropriate means for accomplishing these objectives. But before concluding that it is, attention must be given to other techniques for achieving the same goals. These include conferences, interviews, questionnaires, submission of proposed regulations for comment, collaboration in drafting regulations, reception of documentary evidence and written arguments, and utilization of advisory boards and committees. ${ }^{50}$ The choice of procedure-public hearing or one or more of the substitute devices just mentioned-will depend upon a variety of factors. In some instances the proposed regulation may impinge so directly upon important economic interests and involve such controversial and basic policy problems that a public hearing would constitute the best medium for airing views and reconciling differences. But in other situations, the regulation may be so simple and uncontroversial that a public hearing would be completely wasteful, productive only of delay and expense. Or at the other extreme, the subject matter may be so technical and complex that a public hearing would "contribute little to the administrative understanding, in comparison with the rich cargo of information and opinion . . ." to be secured from personal consultation and written comments. ${ }^{51}$ An emergency may require immediate issuance of the

48. See Davis, The Requirement of Opportnnity to Be Heard in the Administrative Process, 51 Yale L. J. 1093 (1942).

49. See Benjamin Report, 297.

50. These devices for securing public participation in the administrative process are more fully discussed in BeNJAMIN REPORT 297-312; GellhorN, FEDERAL AdMINistrative Proceedings 123-144 (1941) ; Rep. Att'y Gen. Codrm. Ad. Proc. 103-105; Davis, note 48 supra; Fuchs, Procedure in Administrative Rule-Making, 52 Harv. L. REv. 259 (1938); Memorandum on Administrative Procedure Bills by Dean G. Acheson, Hearings before Subcommittee on the Judiciary on $S .674, S$. 675, and $S$. 918, 77th Cong., 1st Sess. 827-829 (1941).

51. See Atr'y. Gen. Comm. Ad. Proc., Sen. Doc. No. 186, Part 10, 76th Cong., 3d Sess. 32-33 (1940). And consider the following observation by Mr. Alfred Jaretzki, $J_{\text {R.: }}$ "My own experience $\cdot{ }^{-} \cdot$ is that personal conferences are the most efficient way of making your ideas felt. I think that many lose sight of the fact that the reason for the establishment of many administrative agencies is that the business of the Government has become so complex that there has had to be established, in effect, business bodies to deal with matters in business ways. The old town-hall meeting type of procedure is not appropriate for a great many matters that must be handled 
regulation. In other instances, even where there is no emergency the character of the rule may be such that it must be issued without first referring it to the public. The agency may have already accumulated in its files the necessary information and expression of views. Or advisory groups (broadly representative of the opposing interests in the regulated industry) which continuously cooperate with the agency may prove the most satisfactory means for securing public participation by the affected interests.

Since these, and probably other, ${ }^{52}$ factors should be taken into account in determining the appropriate procedure to be followed in making regulations, it seems clear that a blanket requirement of notice and public hearing is inadvisable. Still, the unquestioned desirability of participation by affected interests, and the failure of many Pennsylvania agencies "to give any notice whatsoever" 53 suggests the propriety of a legislative effort to encourage public participation. Much could be accomplished by enactment of a simple provision: "Each agency shall, to the extent and in the manner it deems desirable, afford interested persons opportunity to participate in the process of making, amending, or repealing regulations." The italicized portion of the provision would make it essentially hortatory. But the varietyeven diversity- of factors to be considered and the importance of retaining for the administrative a flexible area in which it may experimentally develop improved administrative procedures argue convincingly against a more rigid requirement. Of course, adoption of such a general guide for all agencies should not preclude more specific and binding requirements for particular agencies or particular types of administrative functions in any instance in which careful investigation discloses the need for more restrictive and detailed provisions.

The advantage of deferring the effectiveness of administrative regulations is that the period of deferment gives the affected persons time to adjust themselves to the new requirements. Moreover, it may happen that despite careful pre-issuance procedure an important factor has been overlooked. If there is a period of deferred effectiveness, the affected persons will be able to bring the oversight to the attention of the agency, and the agency will be able to correct the error, before

expeditiously. Furthermore, in my experience the average businessman prefers to sit across the table and discuss possible rules and regulations with an agency rather than to appear at public hearings." Hearings before Subcommittee of Committee on the Judiciary on S. 674, S. 675, and S. 918, 77th Cong., 1st Sess. 1296 (1941).

52. E. g., there would appear to be little need for a public hearing where the agency promulgating the regulations is composed of members representative of the affected interests. See Davis, supra note 48, at 1099.

53. "While in a few instances, administrative agencies in Pennsylvania give public notice of one form or another as to the intended promulgation or adoption of new rules and regulations, most of these agencies adopt them without any notice whatsoever to the persons who may be affected by them." JoInt State Government Commission, $o p$. cit. supra note 12 , at 1 . 
rather than after, the regulation becomes effective. ${ }^{54}$ On the other hand, if the interested persons have been fully informed by pre-issuance procedures, or if the regulation, instead of establishing new requirements, relieves persons from requirements imposed by statute or other rules, or, most important, if the public interest demands that the regulation become effective immediately, a fixed requirement of deferred effectiveness becomes unnecessary or undesirable. The 1943 draft of the Joint State Government Commission met this obstacle by providing that the provision for deferred effectiveness could be suspended "in cases in which the Governor shall certify that because of an emergency or other compelling extraordinary circumstances, the public interest requires that the regulation become effective without the delay required for . . . the prior publication of the regulation." ${ }_{55}$ But such a provision "is, in a sense illusory, since one could hardly expect the governor to do anything but follow the advice of the particular agency with respect to the need for immediate effectiveness of the regulation." 58 Here again, it seems clear that reliance must be placed on the good faith and discretion of the agency. Accordingly, if this matter is to be the subject of a recommendation by the Joint State Government Commission, I should suggest the desirability of an essentially hortatory provision expressing the policy of deferred effectiveness, but giving the agency complete discretion as to both the need for any postponement of effectiveness and the length of the period of postponement.

\section{(2) Publication of Regulations}

Accepting the scarcely debatable proposition that administrative regulations having the effect of law should be brought to the attention of the affected citizen, the problem becomes one of deciding upon appropriate means for achieving the desideratum. The chaos in the federal field was strikingly exposed in the case of Panama Refining Co. v. Ryan in which Chief Justice Hughes noted that "the persons affected, the prosecuting authorities, and the courts were alike ignorant" of the fact that the administrative regulation in question had been repealed by an executive order. ${ }^{57}$ Shortly after this decision, Congress passed

54. See testimony of Mr. Dean G. Acheson, Hearings before Subcommittee of the Committee on the Judiciary on S. 674, S. 675 and $S .918,77$ th Cong., 1st Sess. 813814 (1941) ; Rep. Att'y. Gen. Comm. Ad Proc. 114 (1941).

55. Jornt STATE Government Commission, op. cit. supra note 12, at 17.

56. Nathanson, supra note 26 , at 258.

57. 293 U. S. 388,412 (1935); see Swisher, Selected Papers of Honrer CumMINGS 123-124 (1939). Only a few months before the Solicitor General had moved to dismiss the Government's appeal in a case in which an indictment had been brought and the appeal taken to the Supreme Court in ignorance of the fact that the regulation in question was nonexistent. United States v. Smith et al., 293 U. S. 633 (1934); See Griswold, Government in Ignorance of the Law-A Plea for Better Publication of Executive Legislation, 48 HARv. L. Rev. 198, 204 (1934). 
the Federal Register Act to provide for publication in the Federal Register of all documents of "general applicability and legal effect." ss Two years later the Act was amended to provide for the publication of a codification of administrative regulations and related documents. ${ }^{59}$ Federal administrative regulations thus appear first in the Federal Register, which is published five days a week, and then in codified form in the annual Supplement to the Code of Federal Regulations. ${ }^{60}$

The Pennsylvania Register Act, which was patterned after the Federal Register Act, represented substantial progress in this field in the state. ${ }^{61}$ But, for reasons which are somewhat obscure, the General Assembly repealed the Pennsylvania Act in $1947 .^{62}$ There is considerable virtue in legislation which, like the federal and Pennsylvania register acts, requires codification and publication of existing and future regulations: it enables the interested citizen and his attorney to ascertain what rules are in effect at any particular time, and it has the salutary effect of forcing the agencies, in the process of codifying existing regulations, to re-examine and reappraise the regulations. On the other hand, publication of a register may be expensive. Also, as an informed observer has noted, "As now edited the Federal Register and Code of Federal Regulations are cumbersome and hardly adequate to meet the real needs of citizens and lawyers. Regulations are sometimes omitted; the indices are of limited value; the supplements to the Code have been distributed tardily; and amendments and revisions of regulations have often destroyed the utility of the whole system, as applied to particular subject matters." ${ }^{63}$

Perhaps then it may not be advisable to resurrect the Register, ${ }^{64}$ but instead to adopt the suggestion which has been made to the Joint State Government Commission that agencies be required to file their regulations with the Secretary of the Commonwealth. ${ }^{65}$ My conclu-

58. 49 STAт. 500 (1935), 44 U. S. C. $\$ 301$ et seq. (1940).

59. 50 STat. 304 (1937), 44 U. S. C. \$311 (1940).

60. See Wigmore, The Federal Register and Code of Federal Regulations-How to Use Them, If You Have Them, 29 A. B. A. J. 10 (1943).

61. See note 23 sicpra for a summary of the provisions of the Pennsylvania Act.

62. Pa. Laws 1947, No. 509. The explanation for the repeal given by the Section on Administrative Law is as follows: "Much opposition developed among state agencies against the publication of rules and regulations in the Register and this, together with the physical impossibility of expediting the printing of the second volume of the Register, brought into being House Bill 1211." 53 PA. B. A. REP. 145 (1947).

63. Gellmorn, Administrative Law Cases and Comments 137 (2d ed. 1947). See also Kleps, What Safeguards Should the California Legislature Provide for Administrative Rulle-Making?, 22 Los ANGeles B. BuLl. 201 (1947) and California Division of Administrative Procedure, First Biennial Report 13-17 (1947) for an account of the difficulties experienced by California in its endeavor to publicize administrative regulations.

64. The Section on Administrative Law of the Pennsylvania Bar Association has recommended re-establishment of the Register. See the Section's 1948 report. 19 PA. B. A. Q. 386, 388 (1948).

65. See Phillips, The Attomey General Looks at Administrative Law in Pennsylvania, The Legal Intelligencer, July 6, 1947, p. 1, col. 4. 
sion on this problem is that the Joint State Government Commission must ascertain the facts and be guided accordingly. If in fact the majority of the state agencies now are adequately publicizing their regulations, it would be unwise and unnecessary to impose the additional and costly burden of publication. ${ }^{66}$ But if the facts demonstrate inadequate publication procedures, revival of the Register to correct the inadequacy is in order. ${ }^{.7}$

\section{(3) Judicial and Legislative Review of Regulations}

The Section on Administrative Law of the Pennsylvania Bar Association has consistently favored enactment of a statute authorizing judicial review of administrative regulations in a declaratory judgment proceeding; ${ }^{68}$ and the Joint State Government Commission in its 1943 Report to the General Assembly urged that the Commission be authorized to "nullify any [administrative] rule or regulation, in whole or in part if, in its opinion, the rule or regulation is contrary to an Act of the Assembly." ${ }^{60}$ It is quite apparent, therefore, that the problem of judicial, and probably also, legislative, review of administrative regulations will be considered by the Commission in its present deliberations.

The argument in favor of judicial review of administrative regulations by use of the declaratory judgment procedure runs somewhat as follows. An administrative agency promulgates a regulation which an "aggrieved" person $(P)$ believes is unconstitutional, or is not within the agency's statutory authorization, or was adopted without observance of the procedure prescribed by statute, or is arbitrary or capricious. ${ }^{70} P$ is thereby put in a singularly embarrassing and un-

66. "I have heard a great deal of criticism of the practice of State agencies of not publishing regulations, but actually have had no personal experience with any harm arising from such failure during my term with the present Attorney General." Phillips, note 65 supra.

67. See Stone, Filing and Publication of Administrative Regulations, Publication No. 120, Kansas Legislative Council (1943); Kleps, supra note 63; Moreland, State Administrative Rules and Regulations, 21 MrCH. S. B. J. 22 (1942); Moreland, State Administrative Rules, 7 The Book of the States 171 (1948).

68. See $\$ 305$ of the Section's 1942 draft of the Administrative Agency Law, 48 PA. B. A. Rep. 243 (1942) ; 22 of Sen. Bill No. 95, Pa. Gen. Ass. 1947 Sess.; Report of Section on Administrative Law, 19 PA. B. A. Q. 386, 387 (1948). Section 22 of Sen. Bill No. 95, sponsored by the Bar Association, see 52 PA. B. A. REP. 144 (1947), provides as follows:

"Any person aggrieved by a regulation other than a rate-making, wage-fixing, or price-fixing regulation shall have the right to petition the Court of Common Pleas of Dauphin County for a declaratory judgment to determine the validity of such regulation or the legality of its application to such person or the particular situation presented. . . Said court shall render a declaratory judgment without requiring prior resort to the agency by the person or persons filing the petition. ...

"No regulation shall be declared invalid unless such regulation violates the Constitution of this Commonwealth, or of the United States, or does not come within the statutory authorization of the agency, or was issued without observance of the procedure required by the applicable statute, or is arbitrary or capricious. . "

69. Joint State Government Commission, op. cit. supra note 12 , at $5,7,17$.

70. See second paragraph of the proposed statute, supra note 68 . 
wholesome position: to fail to obey the regulation may subject him to administrative or criminal penalties; while to comply with the regulation would be to acquiesce in administrative action which, it is assumed, he honestly believes is invalid. What then should be done? The answer, of course, has been anticipated: $P$ should institute a declaratory judgment proceeding in which the court will determine the validity of the regulation. If the regulation is invalid, clearly $P$ need not obey; if it is valid, $P$, of course, will conform. Surely, this reasonable procedure, "this speedy and inexpensive means of settling such disputes", ${ }^{71}$ should be specifically authorized by enactment of the proposed statute. ${ }^{72}$ Further, as was said of an analogous federal proposal sponsored by the American Bar Association, since injunctive relief against future administrative action may be obtained where the individual interest is clear and immediate, why should not the same relief be secured through the simple and direct declaratory judgment procedure? ${ }^{73}$

So runs the argument. And an appealing argument it is. Certainly, no one can doubt that cases will continue to arise in which the threat of administrative action will be so grave and the individual interest so clear and immediate that relief should be granted as quickly as possible. But it does not follow that the proposed statute should be adopted. The courts of Pennsylvania like those of other states have found the injunction a convenient and effective means for nullifying invalid administrative regulations. ${ }^{74}$ True, an injunction will not

71. Report of Connittee on Administrative Law, 45 PA. B. A. REP. 344, 406 (1939). For additional comments favoring the declaratory judgment as a procedure for testing administrative regulations, see BORCHARD, DECLARATORY JUDGMENTS c. XIV (2d ed. 1941); Declaratory Judgments in Administrative Law, 11 N. Y. U. L. Q. Rev. 139 (1933) ; Challenging "Penal" Statutes by Declaratory Action, 52 Y ALE I. J. 445 (1943); Stason, supra note 26, at 204; Note, Declaratory Judgments and $A d-$ ministrative Agencies, 15 TEMP. L. Q. 139 (1940).

72. It is not entirely clear why the general declaratory judgment statute, PA. Stat. AnN., tit. 12, $\$ 831$ et seq. (Purdon, 1931), could not be utilized for this purpose. See Jaffe, The Report of the Attomey General's Committee on Administrative Procedure, 8 U. of CHI. L. REv. 401, 438 (1931): "I think that the most hopeful attack on this problem is not more legislation, but an effort to educate the courts in a sensible use of the Declaratory Judgment Act." See also testimony of Mr. Alfred Jaretzki, Jr., Hearings before Subcommittee of Committee on Judiciary on S. 674, S. 675, and $S$. 918, 77th Cong., 1st Sess. 1300 (1941): "I feel if declaratory judgments . . are restricted merely to cases of actual controversy, I am not sure that you have added anything to the declaratory judgment act. If the act goes beyond that, I think it is a mistake."

It is possible, of course, that because the Pennsylvania declaratory judgment statute has at times been given a somewhat restricted interpretation, the sponsors of the proposed legislation desire merely to avoid all question as to the propriety of using the regular declaratory judgment procedure for this purpose. The danger, of course, is, as developed in the text, that the new statute might be interpreted to permit courts to pass upon abstract controversies without the necessary factual background.

73. Report of the Special Committee on Adninistrative Law, 63 A. B. A. RER. 331,335 (1938).

74. Martin v. Baldy, $249 \mathrm{~Pa} .253,94$ Atl. 1091 (1915). See also Bell Telephone Co. of Pennsylvania v. Driscoll et al., $343 \mathrm{~Pa} .109,112,21$ A. 2d 912, 914 (1941): "We have no doubt about the right of the Court of Common Pleas of Dauphin 
be granted unless the requirements for equitable jurisdiction have been satisfied. ${ }^{75}$ It is precisely at this point that I am troubled with the implications of the proposed statute. If it does no more than confirm the power of the courts to invalidate administrative regulations in the type of situation where injunctive relief is appropriate, the statute is unnecessary. If, as is more likely, the statute would expand the power of the courts and permit them to pass upon abstract controversies without the necessary factual background and without exhaustion of available administrative remedies, ${ }^{76}$ it is unwise; and its adoption, by relaxing the principles which should govern the relationships between the administrative and the judiciary, might endanger the continued development of a sound system of administrative justice. ${ }^{77}$

No one can say with certainty how the proposed statute would be interpreted were it enacted. Possibly, the fears expressed would prove groundless. But since the Pennsylvania courts have not been reluctant to use the injunction in appropriate instances and since the proposed statute might reasonably be interpreted to authorize the courts to pass upon basically hypothetical situations in which the primary purpose would be to harass the administrative rather than to relieve the individual from an imminent threat, the balance is against adopting the proposed statute. If, however, careful investigation should reveal instances where injunctive or other procedures now available do not provide adequate relief to private interests, that need should be met by a more precisely drafted statute. Here, as elsewhere, overall reform proposals based upon general theories must give way to selective measures designed to remedy demonstrated defects.

The 1943 proposal of the Joint State Government Commission that it should be empowered to nullify any administrative regulations which in its opinion are "contrary to an Act of the Assembly" has little to commend it. ${ }^{78}$ There is no evidence that the Joint State Government Commission, or any other group of legislators in Penn-

County in the exercise of its equitable powers to entertain a bill to enjoin an administrative agency of the commonwealth from exercising powers not conferred on it or unconstitutionally conferred on it. That point has been decided too frequently to be longer in doubt [citing cases]."

75. See Jaretzki, The Administrative Law Bill: Unsound and Unworkable, 2 LA. L. REv. 294, 310 (1940), discussing an analogous federal proposal: ". . . it must be remembered that the courts will only entertain proceedings for injunctions of this character where the jeopardy to the petitioner is clear and immediate and where, in consequence, a substantial controversy involving a definite state of facts is presented." See also Hollearn et al. v. Silverman et al., $338 \mathrm{~Pa}$. 346, 350, 12 A. 2d 292, 293 (1940).

76. Note that the proposed statute, supra note 68 , specifically provides, "Said court shall render a declaratory judgment without requiring prior resort to the agency by the person or persons filing the petition." See generally, Berger, Exhanstion of Administrative Remedies, 48 Y ALE L. J. 981 (1939).

77. See Comment, 42 Cor. L. Rev. 852, 857 (1942).

78. See note 69 supra; and see the discussion of a somewhat similar Indiana proposal in Legis., Administrative Laze-Legislative Control of Administrative Rules, 41 Cot. L. REv. 946 (1941). 
sylvania or elsewhere, has particular competence to appraise the legality of the diverse and technical regulations of the various state agencies; and its personnel is subject to change with the shifting tides of political fortune. ${ }^{79}$ Also, the determination of legality is not an arithmetical process, and the statute makes no provision for securing the data necessary for an informed judgment. ${ }^{80}$ Further, it is questionable whether the members of the Commission would have the time or the inclination to discharge the routine, onerous task of carefully examining the myriad regulations issued by the agencies. ${ }^{81}$ And if the Commission were to delegate the examination assignment to its staff, it is extremely doubtful whether the benefits to be derived from the Commission's staff checking on the work of the agency's staff, which would have previously passed on the legality of the regulation, are worth the additional expense that would be involved.

There may be instances where, because of the importance of the subject matter, ${ }^{82}$ or the unavoidable vagueness of the legislative standard governing the agency's discretion, ${ }^{83}$ or for other reasons, ${ }^{84}$ it will be desirable to provide for a legislative sharing of the responsibility for administrative regulations. Again, however, the wise course is not one of imposing blanket requirements but of carefully selecting the situations demanding particular treatment. ${ }^{85}$

\section{(4) Judicial Review of Adjudications: The Substantial Evidence Problem}

Section 44 of the Administrative Agency Law authorizes the reviewing court to reverse an adjudication if "any finding of fact made

79. See Hyneman, Tenure and Tumover of Legislative Personnel, 195 ANnaLs 21 (1938).

80. The Commission's proposed statute required only a "conference with the agency" before nullifying regulations. Jornt State Government Commission, op. cit. siipra note 12 , at 17 .

81. Gellhorn, op. cit. supra note 63, at 155. Rep. Atr'y. Gen. Conrar. Ad. Proc. 120 (1941): "Experience, both in England and in this country, indicates that lack of desire, rather than lack of opportunity, has accounted for the absence of legislative interference with administrative regulations."

82. Landis, The Administrative Process 76 (1938): "Frequently the administrative is faced with the need to exercise power that lies within the limits of its statutory grant; but the subject matter happens to be of such great public concern that it is desirable to have the more democratic processes of our government participate in the decision." (1929)

83. Isenbergh, Developments in Administrative Law, 27 VA. L. Rev. 29, 33-35

84. E. g., where the legislature has good reason to believe that the agency or agencies in question customarily act in excess of their delegated powers. See VIRGINIA Advisory Legislative Council, Report on Administrative Agencies, Their CreaTION, JURISDICTION AND Powers 5 (1943) : “. . agencies which are manned, not by state employees, but by members of the vocation and occupation which they purport to regulate, are, for the most part, using the Rule-Making power far in excess of that which could have been reasonably contemplated by the General Assembly ..."

85. Or, as proposed by Landis, of giving the administrative discretion to request legislative approval when in its judgment the regulation is so important that the imprimatur of the Assembly should be secured. Landis, op. cit. supra note 82, at 79. 
by the agency and necessary to support its adjudication is not supported by substantial evidence." ${ }^{86}$ The Section on Administrative Law of the Pennsylvania Bar Association in its 1948 Report recommended amendment of the Agency Law to, "Broaden the power of the reviewing court so as to permit reversal of adjudications if not supported by substantial evidence in view of the entire record . . , " 87

The Report of the Section on Administrative Law does not develop the reasons why the Section desires to "broaden" the reviewing court's power over administrative fact determinations beyond that already provided for in the substantial evidence rule, which is now part of the Agency Law. ${ }^{88}$ It is very possible, however, that the Section's proposal to direct the reviewing court to examine the "entire record" is based upon a fear that the courts of Pennsylvania will so narrowly interpret the substantial evidence provision of the Agency Law as to restrict unduly the court's authority to examine the evidential basis of administrative fact determinations-as, for example, if the courts should decide that the requirement of substantial evidence merely calls for an examination of the record to find some relevant evidence to support the determination, disregarding all contrary evidence of the opposing party. It is true that some scholars apparently read a few decisions of the United States Supreme Court as holding that substantiality may be determined by looking at the evidence of only one side without regard for the evidence of the opposing party ${ }^{89}$ p. 26.

86. The judicial review provisions of the Agency Law are summarized supra,

87. Report of the Section on Administrative Law, 19 PA. B. A. Q. 386, 387 (1948). See also \$ 44 of Sen. Bill No. 95, Pa. Gen. Ass., 1947 Sess. The proposals of the Section also would permit reversal if the adjudication is "arbitrary, capricious, an abuse of discretion or otherwise not in accordance with law." Since the present law already includes a provision for reversal if the adjudication "is not in accordance with law," I can see little reason for adding the "arbitrary, capricious, or an abuse of discretion" clause. Surely, an adjudication which is "arbitrary, capricious, or an abuse of discretion," is not "in accordance with law"; enactment of this phase of the proposal, therefore, might well be construed by the courts as an open invitation to expand the scope of judicial review.

88. See the 1948 Report supra note 87. See also the 1943 Report of Section on Administrative Law, 49 PA. B. A. REP. 170, 171 (1943), stating that the Section had considered and rejected the suggestion that $\$ 44$ of the proposed Agency Law should include the italicized clause in the proposal that the court could reverse or remand the adjudication if "any finding of fact made by the agency and necessary to support its adjudication is not supported by substantial evidence in the light of the whole

89. See Stason, "Substantial Evidence" in Administrative Law, 89 U. OF PA. I. REv. 1026, 1039 (1941); Dickinson, The Judicial Review Provisions of the Federal Administrative Procedure Act (Section 10) Background and Effect, $7 \mathrm{~N}$. Y. U. School of LAW INSTITUTE ProceEdINGS 546, 588, n. 60 (1947); Administrative Law Sympositum, II, 27 A. B. A. J. 207, 209-210 (1941) (comment by Arthur T. Vanderbilt). See also the testimony of Dean Stason in Hearings before Subcommittee of the Committee on the Judiciary on $S .674, S .675$, and $S .918$, 77th Cong., 1st Sess. 1355-1356 (1941) and Hearings before Subcommittee of Committee on Interstate and Foreign Commerce on H.R. 2390, 79th Cong., 2d Sess. 11 (1946). The cases primarily relied upon are NLRB v. Waterman Steamship Corp., 309 U. S. 206 (1940) and NLRB v. Bradford Dyeing Ass'n., 310 U. S. 318 (1940). 
The opinions in the cases contain some language supporting the position that they do sanction such a view. Yet, as Professor Jaffe has noted, "the opinions themselves rehearse a great mass of evidence, much of it from the employers' witnesses, which seems clearly to raise issues capable of being decided either way. It is much too artificial, furthermore, to look upon these cases as involving a pure exercise in 'rationality'. The cases represent the disposition of the Supreme Court to give the Labor Board large leeway in deciding what conduct is wrongful. In other words, the question of the validity of the Court's performance is probably to be argued as much on the substantive as on the procedural level:" 90 And Professor Scanlan argues that the cases relied upon "as horrible examples of the Supreme Court's sanctioning of administrative decisions based on a modicum of evidence, do not appear in that light at all, as any dispassionate reading of the record will confirm." 91

The cases relied upon, then, if they hold as represented, which is at least debatable, represent an aberration and not a generally accepted interpretation of the substantial evidence rule. More important for our purposes, the decisions were made by the United States Supreme Court, not by Pennsylvania courts; and the Pennsylvania courts have not given their approval to the one-sided approach which the federal decisions are said to sanction. ${ }^{92}$ There does not seem to me to be a reasonable possibility that the courts of the Commonwealth would adopt the one-sided approach, particularly in respect to the agencies whose adjudications are governed by the Administrative Agency Law. ${ }^{93}$ On the contrary, it may be anticipated that when the issue is appropriately presented, briefed and argued, the appellate courts of the Commonwealth will hold, as has the New York Court of Appeals, that the substantiality of the evidence is to be judged on "the record considered as a whole." ${ }^{84}$ Certainly, if, as has been stated by the

90. Jaffe, Administrative Procedure Re-Examined: The Benjamin Report, 56 HARV. L. REv. 704, 732 (1943).

91. Scanlan, Judicial Review under the Administrative Procedure Act-In Which Judicial Offspring Receive a Congressional Confirmation, 23 NOTRE DaMe Law. 501, 537 (1948).

92. So far as I have been able to ascertain, neither the Waterman nor the Bradford case, supra note 89 , has been cited by either the Supreme Court or the Superior Court of Pennsylvania. See also Pennsylvania Labor Relations Board v. Kaufman Department Stores, Inc., 345 Pa. 398, 29 A. 2d 90 (1942); Cole et al. v. Pennsylvania Public Utility Commission, 146 Pa. Super. 257, 22 A. 2d 121 (1941).

93. Speaking generally, I should expect that most of the inarticulate factors which influence the scope of judicial review (see ReP. ATT'y GEn. Comm. Ad. Proc. 91 (1941)), would tend to produce a broader review of the orders of the conglomerate group of agencies subject to the Agency Law than of the orders of many of the agencies exempted from that Law.

94. Matter of Stork Restaurant, Inc. v. Boland, 282 N. Y. 256, 275, 26 N. E. $2 d$ 247. 256 (1940) ; see also, Matter of Miller v. Kling, 291 N. Y. 65,50 N. E. 2d 546 (1943): BenJAMIN REPORT 328-340 (1942); Hoyt, Judicial Revieze of Admintistrative 
Supreme Court of Pennsylvania, orders of administrative boards "must be supported by evidence sufficient to convince a reasonable mind to a fair degree of certainty...", 95 the entire evidence must be examined to determine reasonableness.

If the proposal of the Section on Administrative Law is designed merely to insure judicial examination of the entire record when determining substantiality, there cannot be the slightest objection to its purpose. And if assurances could be given that this would be the sole consequence of adopting the proposal, there should be no opposition to its enactment by the Assembly. But, if, as I believe, the unqualified substantial evidence rule, which already is a part of the Agency Law, provides for review of the entire record, the embarrassing question presented is: What interpretation would the Pennsylvania courts give to the additional statutory language? They might, of course, hold that the language was merely a clarifying restatement of existing law. It is equally possible, however, they would feel that the Assembly had given them a new freedom to reverse administrative findings of fact. ${ }^{96}$ For my part, I can see no reason for running the risk that the latter interpretation will be adopted. It is concluded with respect to this reform proposal, therefore, that until the sponsors of the proposal can point with definiteness to an inclination on the part of the Penn-

Determination in the States, in Brochure on Administrative Law, A. B. A. Section on Administrative Iaw 21, 32-33 (1943); and 7 N. Y. U. ScHool of LAW INSTITUTE Proceedings, stipra note 89, at 591, where Mr. Benjamin explained that at the argument in the Court of Appeals in the Stork Restaurant Co. case, counsel for the administrative agency argued first, and after he had been arguing for twenty minutes or so, Judge Lehman said, "Mr. Seward, you have recounted to us evidence in support of the Board's finding that appears to be substantial. I suggest that you now permit the respondent to argue, because the question for the court is whether, against the background of the respondent's evidence, your evidence remains substantial." - thus showing beyond doubt that consideration must be given to the evidence of both sides.

95. Mr. Justice Stern in Pennsylvania Labor Relations Board v. Kaufman Department Stores, Inc., $345 \mathrm{~Pa} .398,400,29$ A. $2 \mathrm{~d} 90,92$ (1942), involving the Pennsylvania Labor Relations Act, $\$ 9$ of which provides ". . . The findings of the board as to the facts, if supported by evidence, shall be conclusive. . . PA. STAT. ANN., tit. 43, §211.9 (Purdon, 1941). See also Cole et al. v. Pennsylvania Public Utility Commission, $146 \mathrm{~Pa}$. Super. 257, $22 \mathrm{~A}$. 2d 121 (1941) in which Judge Rhodes cited Stason, "Substantial Evidence" in Administrative Law, 89 U. OF PA. L. REv. 1026 (1941), note 89 supra. There is no suggestion in Judge Rhodes' reference to Dean Stason's article that either he or the court was approving or adopting its thesis that under the "substantial evidence rule . . . the courts should survey the entire record. ."Id. at 1051 . But it may be of significance that the Superior Court has seen fit to invite attention to the Stason article.

96. See, for example, the statement by Phillips, supra note 65, at col. 5: "I think the suggestion . . . would reduce the agency to the status of an examiner or master appointed to take testimony." And see Dickinson, Judicial Review of Administrative Determinations, a Summary and Evaluation, 25 MINN. L. REv. 588, 596-597, 607-608 (1941), Dickinson, The Acheson Report: A Novel Approach to Administrative Law, 90 U. OF PA. L. REv. 757, 777-778, suggesting that the requirement that findings be supported by substantial evidence "on the whole record" is, with respect to ordinary fact questions, equivalent to the rule articulated in St. Joseph Stock Yards Co. v. United States, 298 U. S. 38 (1935), in regard to "constitutional facts." 
sylvania courts to abnegate their responsibility to study the entire record, the proposal should not be given favorable consideration. ${ }^{97}$

\section{(5) Extension of Coverage of the Administrative Agency Law}

As explained at the outset, although the coverage of the Agency law is stated in broad terms, the Section 51 exemption drastically limits its scope. ${ }^{98}$ Accordingly, it is not surprising to learn that a recommendation has been made that in its current deliberations the Joint State Government Commission should "investigate the feasibility and desirability of extending the coverage of the Administrative Law which is now highly restricted ... [and] should exclude only those agencies which can establish a sound and compelling reason for exemption." 99

The recommendation for an investigation designed to secure the facts which would permit an informed judgment concerning coverage certainly should be encouraged. For there may well be agencies whose adjudications, although now exempt, should be governed by the provisions of the Agency Law. But the recommendation does not go far enough. The definitions of "adjudication" 100 and "agency" 101 are so comprehensive that some administrative actions which should not be governed by the Law probably are brought within its broad sweep. This problem, also, should be investigated by the Commission or other appropriate agency.

Ideally, the investigation to secure the needed information should be a part of a much broader study of the entire administrative structure of the Commonwealth. Such a study would do for Pennsylvania what the Attorney General's Committee and Mr. Benjamin have done for federal and New York administration. ${ }^{\mathbf{1 0 2}}$ Without doubt, an investigation on the plane of those two studies would be expensive and time-

97. Pennsylvania State Board of Medical Education and Licensure v. Schireson, $61 \mathrm{~A} .2 \mathrm{~d} 343$ ( $\mathrm{Pa} .1948$ ), the first appellate case involving $\$ 44$ of the Agency Law, decided after this article was in galley, reversed an order of the Court of Common Pleas of Dauphin County which had affirmed the Board's adjudication revoling Dr. Schireson's license. Justice Drew wrote the majority opinion holding that the Board's finding was not supported by substantial evidence. Since the briefs in the case did not discuss the precise point of whether "substantial evidence" means "substantial evidence in view of the entire record," it is not surprising that the opinion does not expressly resolve the difficulty discussed in the text. However, Justice Drew did state, "We have most carefully examined the entire record and have concluded that the weak and inconclusive evidence adduced by appellee does not rebut the presumption of innocence and that the alleged fraud has not been proved." $61 \mathrm{~A} .2 \mathrm{~d}$ at 347 . In my judgment, the majority opinion clearly reflects a determination of substantiality of the evidence in light of the entire record. Justice Linn, with whom Justices Stern and Steame concurred, dissented in a brief opinion, contending that there was substantial evidence to support the Board's findings and that, "It is not the duty of this court to reweigh the evidence and sit as a super-administrative board." $61 \mathrm{~A} .2 \mathrm{~d}$ at 348 .

98. See p. 25 supra.

99. Report of Section on Administrative Lave, 19 PA. B. A. Q. 386, 388 (1948).

100. See note 18 supra for the definition of "adjudication."

101. See note 20 supra for the definition of "agency."

102. See note 114 infra. 
consuming. But nothing short of such a careful examination will provide the information that is the sine qua non of enlightened action in the field of administrative procedure reform. ${ }^{103}$ If the appropriate officials of the Commonwealth should decide that budgetary considerations preclude such a study, or if it is concluded that piecemeal reform should proceed contemporaneously with the overall investigation, the activities of each agency should be carefully catalogued for the purpose of deciding which particular activities should be governed by the Agency Law. This is needed because the Agency Law imposes a general requirement of hearing for all non-exempted adjudications in accordance with the procedures set forth in Sections 31-34 of the Law. The adjudication provisions of the Federal Administrative Procedure Act and the Model Act, on the other hand, are applicable only to those adjudications, in the case of the Federal Act, which are "required by [another] statute to be determined on the record after opportunity for an agency hearing", ${ }^{104}$ and in the case of the Model Act, which are required "by law or constitutional right to be determined after an agency hearing." 105 As broad and general as those requirements are, they are much more precise and selective than the provisions of the Pennsylvania statute. Accordingly, I would urge the Commission to recommend amendment of the Law so as to enumerate with precision the agency activities to be governed by its provisions.

\section{(6) Establishment of a Division of Administrative Procedure}

Experts have an important role in contemporary government, not only in the realm of fact-finding but in the field of policy as well. Experts, however, do not and should not have an unlimited final say. Out governmental system has given the regular judiciary a powerful role in curbing the excesses of expertise and in making basic policy choices. But the functions to be performed by judicial review are limited. Factors such as the great volume of administrative adjudication, the cost of court litigation, the necessity for quick action, and the vast area of administrative action which is not subject to judicial review drastically restrict the effectiveness of court review of administrative action. ${ }^{106}$

103. It is possible that the study undertaken by the Joint State Government Commission in 1941-42, see p. 23 supra, produced much of the needed data. Judged, however, in terms of the report resulting from the study, note 12 supra, it is extremely doubtful that the study was sufficiently comprehensive or intensive to provide the desired information. The report consisted of 23 pages of which 15 were devoted to the text of proposed legislation; with which compare the 369-page main report and 1400 odd pages of supplementary reports of the Benjamin study.

104. See $\S 5$ of the Federal Act.

105. See $\S 1(3)$ of the Model Act.

106. "Candor compels me to admit, however, that the remedy of judicial review, in most cases, has no practical content. Business transactions cannot wait upon the exigencies of appeal." Remarks of Chester T. Lane, then-General Counsel Securi- 
Similarly, the safeguard to private interests to be found in the opportunity for a formal administrative hearing is often illusory. To take an example from the federal field: During the first twelve years of the Securities and Exchange Commission's administration of the Securities Act of 1933, 6,572 registration statements were filed. ${ }^{107}$ Of this number 5,341 became effective and 913 were withdrawn; in only 182 cases were stop orders issued after formal administrative proceedings. ${ }^{108}$ Of the 182 stop order cases, there were only three instances in which the registrant sought judicial review; ${ }^{109}$ and in no case was the Commission's order reversed. The fact of the matter, of course, is that issuers and underwriters of securities are not interested in administrative or court litigation. Their objective and the objective of their counsel is to "clear" the registration statement with the staff of the Corporation Finance Division of the Commission and to secure the Division's blessing to "acceleration" of the effective date of the statement. Accordingly, if, after the registration statement has been filed, the staff suggests to the registrant that the statement contains "deficiencies", the procedure is either to convince the staff (in rare instances, the Commission itself) that the statement is not deficient or to file an amendment to the registration statement correcting the alleged deficiency. To resist the staff to the bitter end and to rely upon one's ability to prove in the formal stop order proceedings that the statement actually contains no deficiencies would be folly. In the words of the Attorney General's Committee on Administrative Procedure, ". . . even where formal proceedings are fully available, informal procedures constitute the vast bulk of administrative adjudication and are truly the lifeblood of the administrative process. No study of administrative procedure can be adequate if it fails to recognize this fact and focus attention upon improvement at these stages." 110

Therefore, while not minimizing the importance of reform in the fields of judicial review and formal administrative procedure, it appears to me imperative that attention also be directed to the informal administrative process. Because administrative procedure reformers as well as other students of the administrative process have largely overlooked this important segment of the administrative process, there is relatively

ties and Exchange Commission, in Symposium on Administrative Lave, 9 AM. L. School REv. 162 (1939). See also Rep. Atr'y. Gen. Comms. Ad. Proc. $76-77$ (1941); BENJAMIN REPORT 15-16.

107. 12 SEC ANN. REP. 6 (1947).

108. Ibid.

109. Austin Silver Mining Company et al. v. Securities and Exchange Commission et al., 1 SEC JuD. DEc. 732 (C. A. D. C. 1939) ; Oklahoma-Texas Trust v. Securities and Exchange Commission, 100 F. 2d 999 (C. C. A. 10th 1939); Unity Gold Corp. v. Securities and Exchange Commission (C. C. A. 9th 1939 (unreported)). Cf. Jones v. Securities and Exchange Commission, 298 U. S. 1 (1936).

110. Rep. Atr'y. Gen. Comm. Ap. Proc. 35 (1941). 
little information and observation on the subject. ${ }^{111}$ Detailed information on the informal procedures of the various Commonwealth agencies almost certainly is not readily available. It is thus apparent that reform at this level could not practicably be considered by the Joint State Government Commission in its current study. Furthermore, it is almost certain that as a practical matter, informal procedures could not effectively be imposed or controlled by legislation. It seems to me, therefore, that in order fruitfully to study and improve the informal administrative procedures, the Commonwealth should, as California did in $1945,{ }^{112}$ establish a Division of Administrative Procedure to devote constant attention to improvement of the administrative process in the Commonwealth.

Although improvement of informal administrative procedures would be a prime objective of the Division, other equally important functions should also be assigned to it. These would include: ${ }^{113}$

1. Studying the formal (as well as informal) administrative procedures and judicial review of administrative action of the agencies of the Commonwealth with a view to recommending general and specific improvements. ${ }^{114}$

2. Transmitting such information and making such recommendations to the agencies as might facilitate the uniform adoption, wherever practicable and desirable, of procedures which have proved most satisfactory.

3. Assisting the agencies, upon their request, with regard to procedural problems, including, for example, the drafting of procedural rules. ${ }^{115}$

111. The subject is discussed in Rep. Atr'y. Gen. Comm. Ad. Proc. c. III (1941); Gelleorn, op. cit. sipra note 50, c. II; Chamberlain, Dowling and Hays, The Judicial Function in Federal Administrative Agencies 9-14 (1942) ; Blair-Smith, Forms of Administrative Interpretation under the Securities Laws, 26 Iowa L. Rev. 241 (1941).

112. Cal. Laws 1945 , c. 869 . See also Judicial Coumcir of California, Tente BIENNIAL REPORT 10-12 (1944), proposing establishment of a Department of Admininistrative Procedure.

113. Both Mr. Benjamin and the Attorney General's Committee on Administrative Procedure recommended the establishment of a division or office of administrative procedure, and the list of functions suggested in the text is based largely upon their recommendations. Benjamin Report 18-21; Rep. Att'y. Gen. Comm. Ad. Proc. 123-124, 193-194 (1941).

114. It is possible that the proposed Division should make the initial comprehensive study recoinmended, sipra p. 44 . Offhand, however, I am inclined to think that more would be gained from an investigation undertaken by a special group or individual.

115. It should be noted specifically that the Division would have no power to impose its views or recommendations upon the agencies. To give the Division authority, for example, to prescribe procedural rules for the agencies would, in my judgment result in an undesirable division of responsibility between the agencies and the Division. Mr. Benjamin expresses a similar opinion, BENJAMIN REPORT 19. But see SEN. BILL No. 530, Pa. Gen. Ass., 1945 Sess., authorizing the Department of Justice to prescribe rules of practice for Pennsylvania administrative agencies; needless to say, in my opinion, proposals such as contained in SEN. BILL No. 530 should not be approved by the Joint State Government Commission. 
4. Receiving and investigating criticisms and suggestions made by the public regarding the procedure of particular agencies, and reporting thereon to the complainant and agency involved.

5. Administering the Pennsylvania Register or other publication medium.

6. Making annual or more frequent reports to the Governor and the General Assembly concerning the work of the Division, the reports to include such recommendations for legislation or otherwise as the Division deems appropriate.

An adequately staffed Division charged with these responsibilities should be able to effect fruitful reform in both formal and informal procedures of Commonwealth agencies. ${ }^{116}$ Both $\mathrm{Mr}$. Benjamin and the Attorney General's Committee found that the agencies welcomed suggestions for improvement. Mr. Benjamin further emphasized the importance of providing an independent organ to which private parties could bring their complaints and suggestions. And the Attorney General's Committee was impressed "by the possibilities for greater uniformity in many subordinate particulars ... [and] by the absence in many agencies of information or interest concerning the procedures in other parts of the Federal administrative establishment." ${ }^{117}$ These observations, which in the main would also be applicable to Pennsylvania, forcefully suggest the desirability of establishing an organization to study and improve administrative procedures in the Commonwealth.

To paraphrase the statement made by John Foster Dulles in commenting on a similar proposal made by the Attorney General's Committee: This is the most important and most constructive proposal which the Joint State Government Commission might consider. The task of administrative procedure reform is so vast that even after years of effort by the bar of the Commonwealth much still remains to be explored. Further, the administrative process is in constant flux. When new commissions are established or when old commissions meet new situations or assume new tasks, their procedures are differentand should be different-from those appropriate to the regulation of a field which has been well explored. Initially these must be tentative, exploratory decisions in particular cases. Later the principles of these decisions, when tested and to the extent proved valid, may be embodied in semi-permanent rules of general applicability. Many of the differences between the proponents of flexibility and diversity and the ad-

116. Mr. Benjamin estimated that a Director and two assistants, along with a modest stenographical and clerical force, would have been sufficient for the proposed New York Division of Administrative Procedure. BenJanIn Report 21.

117. Rep. Att'y. Gen. Comm. Ad. Proc. 123 (1941). 
vocates of greater uniformity are not so much difference in principle as difference in regard to the proper timing of a standarization which would agree to be ultimately salutary and practical. It is thus of vital importance that the field should be under constant survey and study. Quite apart from substantive legislation which may result therefrom, the continuing existence of an investigatory body will, itself, serve to stimulate administrative agencies to self-effort toward the detection and elimination of faulty procedures and incompetent personnel. The existence of an outside agency authorized to receive complaints will do much to reassure a public which is restive because it feels that it at present can bring its grievances only to the very party by which it feels aggrieved. The Division of Administrative Procedure can serve so greatly to improve the working of the administrative process that its creation would reduce to secondary importance the other legislative proposals to be considered by the Joint State Government Commission. ${ }^{118}$

\section{ConcLUSION}

Doubtless, other reform proposals will come before the Joint State Government Commission. ${ }^{118}$ Still other topics which have been the subject of legislation in other states and the federal government probably will not be considered by the Commission in its present deliberations. ${ }^{120}$ Considerations of space preclude discussion of such matters here. But what has gone before discloses my conception of the manner in which administrative procedure reform should proceed: generalizations and abstract principles are suspect; allegations of deficiencies and evils are to be thoroughly investigated; if investigation discloses weaknesses, specific measures carefully tailored to correct particular defects are to be proposed; affected agencies and private interests are to be given an opportunity to appraise the proposed remedy before it is thrust upon them. The method of patiently pursuing facts and preparing remedial measures in light of the specific evil disclosed is costly, slow and unspectacular. Yet it is clear to me that only through such rational processes will meaningful and lasting reforms be achieved.

118. Dulles, The Effect in Practice of the Report on Administrative Procedure, 41 CoL. I. Rev. 617, 618-619 (1941). See also Dickinson, The Acheson Report: $A$ Novel Approach to Administrative Law, 90 U. of PA. L. REv. 757, 779 (1942): "The Committee's recommendation that a permanent organization to be known as the 'Office of Administrative Procedure' shall be set up to carry on its work in this field is perhaps the most fruitful item in its report."

119. E. g., the proposal of the Section on Administrative Law that appeals from the Court of Common Pleas should be taken to the Superior Court instead of "to the Superior or Supreme Court as in other cases." Report of Section on Administrative Law, 19 PA. B. A. Rep. 386, 387 (1948).

120. See the various provisions of the Federal Administrative Procedure Act, of the Model Act, and the recent enactments discussed in Nathanson, supra note 26. 
The basic and therefore recurring problem of administrative law is how to secure effective governmental regulation within the framework of a democratic, constitutional political system. Or, in the felicitous prose of Justice Frankfurter, "How to fit ancient liberties, which have gained a new preciousness, into solution of those exigent and intricate economic problems that have been too long avoided rather than faced, is the special task of Administrative Law." ${ }^{121}$ As we are often reminded, there is a danger that we shall lose our liberties to the bureaucrats. There is also a danger-to which our attention is not so often invited-that an indiscriminate imposition on the administrative of procedures originally designed to govern the business of courts, or an undue extension of judicial control over administrative action, may make the administrative an impotent instrument for social control. And if it should occur that government finds itself unable to cope effectively with the problems of an industrialized society, the threat to our liberties will be far graver than any to be attributed to bureaucracy. I do not wish to be understood as "viewing with alarm." I desire simply to emphasize that in considering the problem of state administrative procedure reform in a federal political system and an industrialized economy, due consideration must be given to the desirability of maintaining an effective regulatory process.

121. Frankfurter, Foreword, 41 CoL. L. REv. 584, 586 (1941). 